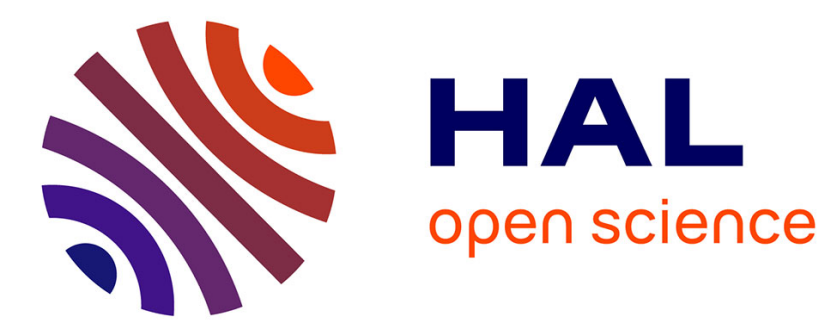

\title{
Do Groups Exclude Others More Readily Than Individuals in Coalition Formation?
}

Ilja van Beest, Rudy B. Andeweg, Lukas Koning, Paul A. M. van Lange

\section{To cite this version:}

Ilja van Beest, Rudy B. Andeweg, Lukas Koning, Paul A. M. van Lange. Do Groups Exclude Others More Readily Than Individuals in Coalition Formation?. Group Processes and Intergroup Relations, 2008, 11 (1), pp.55-67. 10.1177/1368430207084846 . hal-00571676

\section{HAL Id: hal-00571676 https://hal.science/hal-00571676}

Submitted on 1 Mar 2011

HAL is a multi-disciplinary open access archive for the deposit and dissemination of scientific research documents, whether they are published or not. The documents may come from teaching and research institutions in France or abroad, or from public or private research centers.
L'archive ouverte pluridisciplinaire HAL, est destinée au dépôt et à la diffusion de documents scientifiques de niveau recherche, publiés ou non, émanant des établissements d'enseignement et de recherche français ou étrangers, des laboratoires publics ou privés. 


\title{
Do Groups Exclude Others More Readily Than Individuals in Coalition Formation?
}

\author{
Ilja van Beest, Rudy B. Andeweg, Lukas Koning and \\ Paul A. M. van Lange \\ Leiden University and Free University
}

\begin{abstract}
The present research compared interindividual and intergroup coalition processes. We examined whether groups are more likely to form small coalitions than individuals, and whether this tendency would depend on the social value orientation of the coalition party. Consistent with our hypothesis, results revealed that proselfs formed more small coalitions in intergroup settings than in interindividual settings whereas prosocials formed a similar number of small coalitions in both intergroup and interindividual settings. These and complementary findings add credence to the claim that people who are self-oriented are more likely to exclude others to maximize their own payoff and that such processes are especially pronounced in intergroup settings.
\end{abstract}

KEYWORDS coalition formation, discontinuity effect, exclusion, multiparty negotiation, social value orientations

Conflict may involve few or many parties. Each party, in turn, may represent few or many people. This difference in number and size of parties involved is also reflected in theorizing about conflict (Bazerman, Curhan, Moore, \& Valley, 2000; De Dreu \& Carnevale, 2003). First, research on the size of a party has emphasized that one should not equate findings on the individual level to the group level. This interesting line of research has revealed that group decisions may be substantially different from individual decision making (Davis, 1992; Kerr, MacCoun, \& Kramer, 1996). Second, research on the number of parties involved in conflict have stressed that moving from a two party setting to a three or multiparty setting introduces a new factor in the negotiation process (Beersma \& De Dreu, 1999; Crump \& Glendon, 2003; Poltzer, Mannix, \& Neale, 1998; Van Beest, Wilke, \& Van Dijk, 2003). Whereas parties in a two party setting either reach an agreement or not, parties in a three party negotiation have more freedom because they can choose with whom to negotiate. An important difference between a two and a multiparty negotiation setting therefore is that

\footnotetext{
Author's note

Address correspondence to Ilja van Beest, Department of Social and Organizational Psychology, Leiden University, PO Box 9555, 2300 RB Leiden, The Netherlands [email: vanbeest@fsw.leidenuniv.nl]
} 
the latter allows the formation of coalitions in which some parties are included and others are excluded from an agreement. As such, coalition formation helps researchers to understand when exclusion or ostracism is likely to occur (Williams, 2001; Zadro, Williams, \& Richardson, 2004, 2005).

Interestingly both the research on the size of a party and the research on the number of parties involved have been conducted in relative isolation. Research emphasizing the size of a party has focused on two party situations (but for an exception see, Insko et al., 1994). Research on multiparty negotiation, or more specifically coalition formation, on the other hand, has focused on individuals thereby ignoring that many decisions are not made by individuals but instead by groups of individuals (e.g. political parties). The aim of the current article, therefore, was to assess how moving from the individual level to the group level affects coalition behavior. We assessed when groups are more likely than individuals to exclude others from a negotiated agreement and reasoned that in order to answer this question one has to consider what members of a coalition party value.

\section{Previous coalition research}

Early theorizing about coalition formation assumed that people are primarily motivated by self-interest (for a review of coalition theories see Komorita \& Parks, 1995; Murnighan, 1978a). Several theories have been proposed, some stressing power differences, others stressing differences in resources, but all assuming that people use these differences to maximize their own payoff (Van Beest, Van Dijk, \& Wilke, $2004 \mathrm{~b})$. In line with this theorizing one of the most replicated findings of coalition research is that parties would rather share payoffs with few others in a small coalition than with many others in a large coalition (e.g. Gamson, 1964; Komorita \& Meek, 1978; Michener, Fleishman, Vaske, \& Statza, 1975; Murnighan, 1978b; Willis, 1962). For example, three people negotiating about 60 euros should be more likely to form two person coalitions in which both members obtain 30 euros than three person coalitions in which each member obtains 20 euros.
Note, however, that most of these theories were developed in the 1960s and 1970s. Consequently key insights about human judgment and decision making that have been developed in the last few decades have not been incorporated in our understanding of coalition behavior. Indeed, as Komorita and Parks already argued in 1995 , much is still to be learned about coalition formation. Taking up this challenge, recent coalition research has taken a different approach to study coalition formation. In contrast to comparing predictive outcomes of various coalition theories, this new approach is more focused on underlying processes assuming that coalition formation is best understood in terms of both self-interest and more other-oriented concerns such as fairness (Van Beest, Van Dijk, \& Wilke, 2004a).

Based on this new approach, several studies have now shown that coalition players are sometimes reluctant to form small coalitions and that they may form unnecessarily large coalitions instead. These studies have manipulated the relation between self-interest and fairness by considering situational and personality constraints. For example, although coalition players are likely to exclude others when they can obtain a distributively fair share of the payoff in a small coalition, they are less likely to exclude others when they cannot obtain a distributively fair payoff share in a small coalition (Van Beest et al., 2004a). In fact, when it is difficult to simultaneously satisfy self-interest and fairness, people may form unnecessary large, but distributively fair, coalitions instead. Other studies focused on personality differences (Van Beest, Van Dijk, De Dreu \& Wilke, 2005; Van Beest et al., 2003). These studies have shown that people who are more other-oriented are less likely to form small coalitions than people who are more self-oriented. Taken together there is now increasing evidence that coalition behavior is not only instigated by pure self-interest, or self-oriented max own considerations as suggested by classic coalition theories, but also by more other-oriented considerations such as the extent to which forming a small coalition is perceived to be harmful for excluded players, instigating players to form unnecessary large coalitions instead. 
What we like to stress in the current contribution is that both the classic work and these more recent insights on coalition formation are based on coalition games in which individuals negotiate with other individuals. Consequently, a major caveat of coalition research is that it has ignored situations in which groups need to form coalitions in order to achieve a desirable outcome. This is surprising because many reallife situations are not characterized by coalitions between individuals but, instead, by coalitions between groups (e.g. political parties).

\section{Individual and group behavior in other mixed-motive settings}

The question of how interindividual may differ from intergroup behavior has been investigated in mixed-motive situations other than coalition formation. For example, numerous experiments by Insko and colleagues on the Prisoner's Dilemma game have shown that conflicts between groups are more competitive than conflicts between individuals (for reviews see Schopler \& Insko, 1992; Wildschut, Pinter, Vevea, Insko, \& Schopler, 2003). Three complementary reasons have been advanced to explain this interindividual-intergroup discontinuity effect. First, the social support explanation proposes that intergroup interactions are more competitive than interindividual interactions because group members can provide mutual support for the pursuit of self-interest, whereas such social support is not available to individuals. Second, the identifiably explanation proposes that intergroup interactions are more competitive than interindividual interactions because groups provide a shield of anonymity facilitating the pursuit of self-interest. Finally, the schema-based distrust explanation proposes that intergroup interactions are more competitive because the anticipation of interacting with another group activates an out-group schema, consisting of learned beliefs and expectations that intergroup interactions are aggressive and competitive.

Apart from these explanations that are based on a combination of increased greed and increased fear of exploitation, other researchers have argued that groups may just have a better understanding of the strategic aspects of a situation and thus more likely to understand how they can maximize their payoffs than individuals alone (Bornstein, Kugler, \& Ziegelmeyer, 2004; Bornstein \& Yaniv, 1998). For example, research on the Ultimatum Bargaining Game, has shown that groups offer less to other groups than individuals offer to other individuals (Bornstein \& Yaniv, 1998).

Using the above findings to generate predictions about intergroup coalition formation, the reasoning so far would suggest that groups should be more competitive, and more concerned with their own payoff, and thus more likely to exclude than individuals. However, we propose that this conclusion is but half the story. To draw a more complete picture we argue here that one also has to consider what members of coalition party value. Following the general assumption of interdepence theory (Kelley \& Thibaut, 1978; Rusbult \& Van Lange, 2003), and more specifically research on social value orientations (De Cremer \& Van Dijk, 2002; De Kwaadsteniet, Van Dijk, Wit, \& De Cremer, 2006; Joireman, Kuhlman, Van Lange, Doi, \& Shelley, 2003; Messick \& McClintock, 1968; Van Lange, Otten, De Bruin, \& Joireman, 1997), we reasoned that social interactions of coalition parties are not only shaped by concerns about their own payoff (i.e. self-interest) but also by broader social or interindividual concerns, such as concern with joint outcomes, concern with others' outcomes, and concern with equality in outcomes.

Given this distinction, we proposed that the social value orientation of a coalition party should moderate the magnitude of the difference between individual and group coalition formation. Parties that consist of individuals who are predisposed to enhance their own payoffs in either an absolute or relative manner (i.e. individuals with a proself orientation) may indeed be more likely to form small coalitions in an intergroup setting than in an interindividual coalition setting. However, parties that consist of individuals who are predisposed to attain equality in payoffs and aim to maximize joint payoffs (i.e. individuals with a prosocial orientation) may be less inclined to form more small coalitions in 
an intergroup than in an interindividual coalition setting. Indeed, assuming that prosocials have a greater threshold for forming small coalitions than do proselfs (Van Beest et al., 2003), we argued that variables associated with intergroup interaction (e.g. social support, schema-based distrust) should have a lesser impact on the competitiveness of prosocials as compared to proselfs. A lot has to happen for prosocials to form small coalitions; little has to happen for proselfs to forms small coalitions

\section{Current research}

To test our reasoning we used an experimental paradigm that has been successfully tested in previous experiments on individual coalition behavior. An important aspect of this paradigm is it that uses three party coalition games in which parties are equal on all possible levels of comparison. The advantage of this set-up is that it narrows the range of possible outcomes to two different types-either parties form a small two party coalition or a grand three party coalition-and thus to the basic question whether parties are willing to exclude others in order to maximize their own payoffs. Furthermore, because all parties are equal on all possible levels the distributively fair thing to do is to form a coalition in which coalition members obtain an equal payoff share. This makes it easy to compute how parties allocate payoffs within a coalition. Either they give every coalition member an equal share or they do not. Another advantage of the paradigm is that parties negotiate by means of a computer interface. This inhibits possible confounding factors that are present in faceto-face bargaining (Bazerman et al., 2000) and allowed us to assess our hypothesis in terms of what parties wanted, what parties got, and how difficult it was to reach an agreement.

\section{Method}

\section{Participants and design}

Participants were 180 students from Leiden University (mean age $=20.90, S D=2.97$ ) assigned to the role of a coalition party (A, B, or C) in a three party coalition game. The design was a 2 (coalition game: interindividual vs. intergroup) $\times 2$ (social value orientation: prosocial vs. proself) design. In the intergroup games participants negotiated as dyads with two other dyads. In the interindividual games participants negotiated as individuals with two other individuals. Consequently, the analyses were not based on 180 observations but on 120 observations (60 dyads and 60 individuals).

\section{Procedure}

Participants were approached at Leiden University and asked to access a website. On this website participants filled out a computer version of the nine-item decomposed games measure of social value orientation (Messick \& McClintock, 1968; Van Lange \& Kuhlman, 1994). The Decomposed Games measure has excellent psychometric qualities. It is internally consistent (e.g. Parks, 1994), reliable over substantial time periods (Eisenberger, Kuhlman, \& Cotterell, 1992), and is not related to measures of social desirability (e.g. Platow, 1994).

Based on this measure individuals can be classified as prosocials (i.e. people that value equality and max joint), competitors (i.e. people that value max diff), and individualists (i.e. people that value max own). Similar to other research and because there were no theoretical reasons why individualists or competitors should differ in their preference for forming a small coalition (i.e. a small coalition maximizes one's payoff in an absolute and in a relative way), we combined the individualists and competitors into one group of proselfs. After participants had filled out the questionnaire they were told to leave their name and phone number and informed that an assistant would get in touch with them to make an appointment for the coalition study. Unknown to the participants, we only made appointments with participants who had been classified as prosocials or as proselfs. In some lab sessions we only invited prosocial participants in other lab sessions we only invited proself participants.

We introduced our manipulation of coalition game when participants entered the laboratory. In the interindividual game, participants were seated alone behind a computer. In the intergroup 
game, participants were seated together behind a computer. ${ }^{1}$ After the participants were seated in their separate cubicles, we explained the format of the coalition game and the negotiation procedure.

The format of the coalition game was based on the landowner paradigm (Van Beest et al. 2003, $2004 b, 2005)$. In the current version we told participants that they owned one parcel of land with an assessed value of 20,000 euros. Next, we informed participants that a project developer was interested in buying at least two parcels for a fixed prize of 60,000 euros and that unsold parcels would lose all their value. The project developer would not object to more land but would not pay more for it. To make the game more engaging we noted that whatever participants managed to get for their parcel would form the basis of their experimental payoff. They were informed that there were several prizes of 50 euros and that obtaining a good bargaining outcome would maximize their chance of winning 50 euros. After this information, we repeated that both the two party coalitions (AB-, AC-, and BC-coalition) and the three party coalition (ABC-coalition) met the demands of the project developer, and that each coalition party basically faced the decision of whether they wanted to form a small coalition in which they could share 60,000 euros with one other party or a grand coalition in which they had to share 60,000 euros with two other parties.

The negotiation procedure was based on a procedure introduced by Kahan and Helwig (1971). In this procedure all parties are asked to formulate a coalition proposal, stating what coalition they wanted to form and how they wanted to allocate the payoff. After receiving the proposals, each party was asked to select the proposal it wanted to execute. When all parties included in a coalition proposal chose to execute the proposal, a tentative coalition was formed. Possible excluded parties were then given the opportunity to formulate a counterproposal. Subsequently, parties could either ratify the tentative coalition to make it final or switch to the new proposal of the excluded party to form a new tentative coalition. When parties failed to reach an agreement in the first place, all parties were asked to formulate an opening proposal again. This process was repeated until a final coalition was formed.

At the end of the experiment all participants were thanked and given a ticket with a number they had to remember until the last meeting of the introductory psychology course. During the class meeting, participants were thoroughly debriefed and three participants were awarded 50 euros ( 1 participant from the interindividual coalition game and 1 dyad from the intergroup coalition game).

\section{Results}

\section{Game checks}

All coalition parties recalled what was offered by the project developer, $99 \%$ of all coalition parties recalled the initial value of their parcel, $99 \%$ of all coalition parties recalled how much an excluded party would obtain. All parties understood which coalitions they could form to meet the demands of the project developer. These percentages did not differ between conditions (all $\left(\chi^{2} s<1\right)$. This indicates that participants were well informed on the main elements of the experiment.

\section{Preferred coalition and payoff allocation}

We hypothesized that proselfs should be more affected by our manipulation of interindividual and intergroup coalition formation than prosocials. To test this hypothesis we first analyzed coalition preference and allocation preference (see Table 1 for coalition preference and Table 2 for payoff preference).

To analyze coalition preference, we assessed whether a party wanted to form a small coalition (i.e. $\mathrm{AB}-, \mathrm{AC}$ - or BC-coalition) or a grand coalition (i.e. ABC-coalition). A loglinear analysis with social value orientation (proself vs. prosocial), game type (interindividual vs. intergroup), and coalition preference (small coalition vs. grand coalition) showed that participants preferred small coalitions $(63 \%)$ to grand coalitions $(27 \%)\left(\chi^{2}(1, N=120)=8.64, p<.01\right)$, and showed that proselfs $(80 \%)$ were more willing to form small coalitions than prosocials $(47 \%)\left(\chi^{2}(1, N=120)=15.08, p<.001\right)$. It also 
Table 1. Frequency of preferred coalitions by social value orientation and game type

\begin{tabular}{|c|c|c|c|c|}
\hline & \multicolumn{2}{|c|}{ Prosocial } & \multicolumn{2}{|c|}{ Proself } \\
\hline & Interindividual & Intergroup & Interindividual & Intergroup \\
\hline Small coalitions & 14 & 14 & 20 & 28 \\
\hline Grand coalitions & 16 & 16 & 10 & 2 \\
\hline
\end{tabular}

Table 2. Frequency of preferred payoff allocation by social value orientation and game type

\begin{tabular}{lccrrr}
\hline & \multicolumn{2}{c}{ Prosocial } & & \multicolumn{2}{c}{ Proself } \\
\cline { 2 - 3 } & Interindividual & Intergroup & & Interindividual & Intergroup \\
\hline Equal & 24 & 23 & 22 & 18 \\
Unequal & 6 & 7 & 8 & 12 \\
\hline
\end{tabular}

yielded the predicted interaction between social value orientation and game type on coalition preference $\left(\chi^{2}(1, N=120)=4.54, p<.05\right)$. In agreement with our reasoning, proselfs proposed more small coalitions in the intergroup game $(93 \%)$ than in the interindividual game $(67 \%)$ $\left(\chi^{2}(1, n=60)=7.16, p<.01\right)$, whereas prosocials did not propose more small coalitions in the intergroup $(47 \%)$ than in the interindividual game $(47 \%)\left(\chi^{2}(1, n=60)=0, n s\right)$.

To analyze how parties preferred to allocate payoffs within a coalition, we counted the number of times parties preferred to give all coalition members a distributively fair payoff share (i.e. 30:30 in a small coalition, or 20:20:20 in a grand coalition). A loglinear analysis with social value orientation, game type, and payoff showed that most parties preferred equal payoff allocations $(72 \%)$ to unequal payoff allocations $(28 \%)\left(\chi^{2}(1, N=120)=25.19, p<.05\right)$, and that proselfs $(66 \%)$ were less likely to prefer equal payoff allocations than prosocials $(78 \%)$ $\left(\chi^{2}(1, N=120)=4.95, p<.05\right)$. There was no significant interaction between social value orientation and game type on payoff. However, specific contrasts did show that proselfs preferred equal allocations less in the intergroup game $(60 \%)$ than in the interindividual game $(73 \%)$ $\left(\chi^{2}(1, n=60)=6.80, p<.01\right)$, whereas prosocials preferred equality in both the intergroup game $(77 \%)$ and the interindividual game $(80 \%)$ $\left(\chi^{2}(1, n=60)=0.11, n s\right)$.
Combining the results on coalition preference and payoff preference, the message is clear. Not only do they show that proselfs are more willing to exclude others than prosocials, they also show that proselfs prefer unequal allocations within coalitions and that these preferences are augmented in the intergroup game.

\section{Formed coalition and actual payoff allocation}

The next step in our analysis of interindividual and intergroup coalition behavior was to investigate what coalitions were actually formed (see Table 3) and how the payoffs were eventually allocated (see Table 4 ). ${ }^{2}$ The difference between formed coalition and preferred coalition is that preferences are formed prior to the negotiation whereas the actual formed coalition is the result of a negotiation process and thus affected by the coalition choices of others. Consequently, formed coalition and actual payoff allocation are analyzed on the group level.

A loglinear analysis with social value orientation, game type, and formed coalition as variables yielded a formed coalition effect $\left(\chi^{2}(1, N=40)=12.80, p<.001\right)$, and the predicted interaction effect of social value orientation and game type on formed coalition $\left(\chi^{2}(1, N=40)=5.51, p<.05\right)$. The formed coalition effect showed that small coalitions $(78 \%)$ were formed more often than grand coalitions $(23 \%)$. The interaction effect showed 
Table 3. Frequency of formed coalitions by social value orientation and game type

\begin{tabular}{|c|c|c|c|c|}
\hline & \multicolumn{2}{|c|}{ Prosocial } & \multicolumn{2}{|c|}{ Proself } \\
\hline & Interindividual & Intergroup & Interindividual & Intergroup \\
\hline Small coalitions & 8 & 6 & 7 & 10 \\
\hline Grand coalitions & 2 & 4 & 3 & 0 \\
\hline
\end{tabular}

Table 4. Frequency of actual payoff allocation by social value orientation and game type

\begin{tabular}{lccrcr}
\hline & \multicolumn{2}{c}{ Prosocial } & & \multicolumn{2}{c}{ Proself } \\
\cline { 2 - 3 } & Interindividual & Intergroup & & Interindividual & Intergroup \\
\hline Equal & 8 & 8 & 10 & 5 \\
Unequal & 2 & 2 & 0 & 5 \\
\hline
\end{tabular}

that proselfs formed more small coalitions in the intergroup game $(100 \%)$ than in the interindividual game $(70 \%)\left(\chi^{2}(1, n=20)=\right.$ $4.69, p<.05)$, whereas prosocials did not form more, but indeed if anything (not statistically significant), formed fewer small coalitions in the intergroup game $(60 \%)$ than the interindividual game $(80 \%)\left(\chi^{2}(1, n=20)=.96, n s\right)$.

Next, we analyzed how payoffs were allocated in formed coalitions. A loglinear analysis with social value orientation, game type, and payoff yielded an effect of payoff $\left(\chi^{2}(1, N=40)=\right.$ $12.79, p<.01)$, an effect of game type on payoff $\left(\chi^{2}(1, N=40)=3.77, p<.05\right)$, and an interaction effect of social value orientation and game type on payoff $\left(\chi^{2}(1, N=40)=9.88, p<.05\right)$. The payoff effect showed that most coalitions decided to allocate payoffs equally among their members $(78 \%$ vs. $22 \%)$. The game type effect showed that distributively fair allocations were achieved less often in the intergroup game $(65 \%)$ than in the interindividual game $(90 \%)$. The interaction effect showed that proselfs were less likely to obtain distributively fair payoff allocations in the intergroup condition $(50 \%)$ than in the interindividual condition $(100 \%)\left(\chi^{2}(1, n=20)=6.67, p<.01\right)$, whereas prosocials were as likely to obtain distributively fair payoff allocations in the intergroup game $(80 \%)$ and the interindividual game $(80 \%)$ $\left(\chi^{2}(1, n=20)=0, n s\right)$.
These results on formed coalition mirrored the results on coalition preference. Proselfs formed more small coalitions and were less likely to obtain equal payoff share in the intergroup game than in the interindividual game. Prosocials were not affected by our game manipulation. They formed a similar number of small coalitions and obtained equal payoff shares in both the intergroup and interindividual game.

\section{Conflict during negotiations}

To complete our analyses of interindividual and intergroup behavior we took a closer look at the negotiation process itself. To assess the extent to which it was problematic to form a coalition we counted the number of times coalition parties failed to ratify a tentatively formed coalition (see also Van Beest et al., 2004a).

A 2 (social value orientations) $\times 2$ (game type) analysis of variance on this measure of conflict yielded only a main effect of social value orientation $(F(1,36)=4.26, p<.05)$. Independent of game type, proselfs $(M=2.80, S D=2.65)$ failed more often to ratify a coalition than prosocials $(M=1.50, S D=0.89)$. What is more interesting is that it mattered what kind of coalition was eventually formed. Specific $t$-tests that controlled for differences in variance showed that proselfs experienced more conflict when they formed a grand coalition $\left(M_{\text {grand }}=7.67, S D=3.78\right.$ vs. $M_{\text {small }}=$ $1.94, S D=1.44 ; t(2.06)=-2.60, p=.05)$, whereas 
prosocials experienced more conflict when they formed a small coalition $\left(M_{\text {grand }}=1.00, S D=.00\right.$ vs. $\left.M_{\text {small }}=1.71, S D=.99 ; t(13)=2.68, p<.05\right)$. This difference between proselfs and prosocials suggests that negotiations became especially problematic when parties did not satisfy their initial preference.

\section{Discussion}

The primary purpose of the current article was to examine how coalition behavior of groups differs from coalition behavior of individuals. Consistent with our reasoning, results showed that moving from an interindividual coalition game to an intergroup coalition game had a different impact on coalition behavior of proselfs than of prosocials. Proselfs in an intergroup coalition game were more likely to opt for small coalitions and unequal payoff allocations than proselfs in an interindividual coalition game. Prosocials in contrast, preferred to include all and were as likely to form small coalitions in both the intergroup and the interindividual game. This difference between prosocials and proselfs was also apparent in the way they negotiated. Proselfs formed small coalitions faster than grand coalitions. This suggests that proselfs did not find it problematic to exclude others. Prosocials, on the other hand, formed grand coalitions faster than small coalitions. This suggests that prosocials did not find it problematic to include all. Generally, these findings make an important contribution to existing theory and research about group decision making, social value orientation, and coalition formation in particular. In the following, we discuss each contribution, discuss strengths and limitations, and conclude by considering some broader implications.

\section{Coalition formation}

First we discuss how our findings may advance research on coalition formation. One contribution is that the current findings extend previous coalition research showing that other-oriented individuals prefer to include all in an agreement (Van Beest et al., 2003, 2005). Van Beest et al. (2003), for example, assessed how social value orientation affected coalition preferences and showed that prosocials prefer to include all in an agreement when they perceive exclusion as harmful. We replicated this preference effect and showed that preferences are translated to actual behavior. The second and more important contribution is that we extended coalition research by moving from the interindividual level to the intergroup level. We showed that also on this level coalition behavior should not only be understood in terms of self-interest but also in terms of more other-oriented concerns (Van Beest et al., 2004a). Indeed, given that differences in behavior between proselfs and prosocials were more pronounced at the intergroup level than at the interindividual level, it may even be argued that the relative importance of these motivations were augmented at the group level.

A third contribution is that we took a closer look at the negotiation process preceding the formation of a coalition. Regardless of whether participants negotiated in groups or as individuals, results indicated that proselfs had more conflict during negotiations than prosocials, and especially when they ended up forming a grand coalition. This is interesting because from a coordination perspective it has been argued that reaching an agreement between three parties (i.e. forming a grand coalition) should be harder to coordinate than reaching an agreement between two parties (i.e. forming a small coalition) (Gamson, 1964; Komorita \& Parks, 1995; Murnighan, 1978a). We concur, but add that one has to consider what parties value. Forming a grand coalition may indeed be a coordination problem for parties that aim to maximize their own payoffs. It seems to be less problematic for parties that value obtaining equality in payoffs.

\section{Group decision making and social value orientation}

How do our results compare to previous research on differences between group and individual decision making? As we already mentioned in the introduction to this article, this research has shown that groups tend to be more competitive than individuals (Wildschut et al., 2003), and has shown that groups tend to behave more in 
accord with game theoretic predictions (e.g. Bornstein et al., 2004). What we want to stress here is that most of these researchers have focused on mixed-motive situations in which two parties interact (but see Insko et al., 1994). We extended this line of research by introducing a third party to the negotiation table or, more specifically, the possibility that parties could exclude others from a negotiated agreement. In this setting, we reasoned and showed that groups may be more likely than individuals to exclude when they are primarily motivated to increase their own payoffs (i.e. proselfs) but not when they are motivated to obtain equality in payoffs (i.e. prosocials).

Our findings also suggest that differences between prosocials and proselfs may sometimes become even more pronounced in intergroup interaction-a context that has yet to be explored by researchers on social value orientation. As a case in point, past research has shown that proselfs, more than prosocials, tend to evaluate cooperation and competition in terms of intelligence and power, associating cooperation with weakness and stupidity and competition with strength and wisdom (Liebrand, Jansen, Rijken, \& Suhre, 1986; Van Lange \& Kuhlman, 1994). In contrast, prosocials perceive cooperation and competition more strongly in terms of morality, associating cooperation with goodness and fairness and competition with badness and unfairness. Also, prosocials differ from proselfs in terms of their concern with collective outcomes as well as with their concern with equality in outcomes-everybody should get the same (Van Lange, 1999). Taken together, it is possible that prosocials persist in the use of these schemes, preferences, and perceptions in intergroup contexts, whereas proselfs become more strongly concerned with their own outcomes, and even less concerned with morality, fairness, and equality in intergroup contexts.

\section{The norm of self-interest}

Our results also contribute to the literature on the norm of self interest (Miller, 1999). Miller argued that people 'often act and speak in accordance with their perceived self-interest solely because they believe to do otherwise is to violate a powerful descriptive and prescriptive expectation' (Miller, 1999, p. 1052). Interestingly, he posited that this belief may be one of the factors underlying the interindividualintergroup discontinuity effect. In these terms our results would suggest that proselfs are more likely to fall prey to this norm of self-interest than prosocials.

Related to this discussion is the distinction between how people start a negotiation and how they end a negotiation. Referring to the norm of self-interest, Tyler, Huo, and Lind (1999) argued and demonstrated that people enter a negotiation under the assumption that every player is solely interested in maximizing their own financial gains, but leave the negotiation wishing that they had given more attention to relational concerns. We did not directly assess relational concerns, and we did not assess how participants felt after the negotiation ended. For future research, it would be interesting to address this issue and investigate how prosocials and proselfs would feel after the negotiation. On the one hand, one might expect that proselfs would be more vulnerable to experiencing a discontinuity between preferences at the start of the negotiation and post hoc evaluations of a negotiation because they are the ones who are especially likely to put own interests first during the negotiation (see also Beersma \& De Dreu, 2003). On the other hand, one could also anticipate that prosocials would be more susceptible to this post-decision effect because they are more likely to value relational concerns.

\section{Strengths and limitations}

A strong point of the current research is that we focused on behavior. We showed that our manipulations determined what parties wanted, what parties got, and how difficult it was to reach an agreement. We did not, however, assess what coalition parties thought during the negotiation because we feared that this could have disrupted the bargaining. A limitation of our approach is that we therefore cannot disentangle the different approaches that inspired our predictions. For instance, we do not know whether proselfs were more likely to 
form small coalitions in an intergroup setting than in an interindividual setting because of (a) combination of greed and fear of exploitation (Schopler \& Insko, 1992; Wildschut et al, 2003) or (b) because of a better understanding of the payoff structure (Bornstein et al., 2004). This was beyond the scope of the current research as we focused on the common thread underlying these approaches, but further research could for example assess cognitions during bargaining by having participants speak about what they are thinking during bargaining.

Another strong point is that we assessed social value orientations at least two weeks prior to the experiment. This is important because it builds confidence that social value orientation is indeed a relatively stable construct over time (Eisenberger et al., 1992; Van Lange, 1999). Moreover, we did not instruct participants to be prosocial or to be proself. All participants were given the same incentive scheme, namely that their experimental earnings were completely dependent on whatever they managed to obtain during bargaining. A possible avenue of further research is to use different incentive schemes to manipulate social value orientation (i.e. instruct participants to maximize own payoff, or joint payoff, e.g. Beersma \& De Dreu, 1999, 2002, 2003). Although it is worthwhile to recall that a meta-analysis on different operationalizations of social value in negotiation research indicated that assessing personality difference or telling people to be prosocial had similar effects (De Dreu, Weingart, \& Kwon, 2000).

\section{Societal implications}

In closing, it may be relevant to acknowledge some societal implications of the present research. Political scientist have debated for quite some time now that the simple rational choice models of government formation do not provide all the answers (Martin \& Stevenson, 2001). One of the problems is the relatively high incidence of 'oversized' or 'surplus-majority' governments. In fact, 39\% of all governing coalitions in Western European countries between 1945 and 1998 included political parties that were not necessary to obtain a parliamentary majority (cf. Gallagher, Laver, \& Mair, 2001). Political scientists may, however, have been reluctant to consider social psychological approaches to understand why surplus majority governments are formed (Van Beest et al., 2003, 2005) because social psychology experiments were based on individuals and not on groups. In the current research we showed that prosocial groups were more likely to include all than proself groups. This extends previous findings on the individual level to the group level and shows that incorporating differences in social value orientation may be a fruitful addition to rational choice models to understand government formation. We hope that the current findings may therefore increase confidence in social psychological approaches to understand why oversized governments are formed.

\section{Notes}

1. Similar to other research comparing individual and group behavior we used dyads to manipulate groups and not triplets or more. One reason why was that previous research on the discontinuity effects established that competitiveness increases greatly as one moves from one-onone interaction to two-on-two interactions, but slightly as one moves from two-on-two interaction to three-on-three interactions (Wildschut et al., 2003). Another reason was that we did not want to complicate our research by using a nested coalition design. Using triplets or more as a group manipulation has the disadvantage that party members may form within party coalitions to establish what course of action to take. That is, if more than two party members are involved one has to establish a majority decision rule, whereas in the current version all members had to agree about what decision they wanted to make.

2. Data were analyzed with SPSS. This package controls for sampling zeros by adding 0.5 to all cells. The odds ratios within each table showed that this does not alter the pattern of the interactions.

\section{Acknowledgments}

This research was supported by a Veni-grant from the Netherlands Organization for Scientific Research (NWO: 451-04-069) awarded to Ilja van Beest. The authors thank Eric van Dijk, 
and Jan-Willem van Prooijen for their helpful comments on earlier drafts of this article, and Marc de Rooij for his statistical advice on how to analyze categorical data.

\section{References}

Bazerman, M. H., Curhan, J. R., Moore, D. A., \& Valley, K. L. (2000). Negotiation. Annual Review of Psychology, 51, 279-314.

Beersma, B., \& De Dreu, C. K. W. (1999). Negotiation processes and outcomes in prosocially and egoistically motivated groups. International Journal of Conflict Management, 10, 385-402.

Beersma, B., \& De Dreu, C. K. W. (2002). Integrative and distributive negotiation in small groups: Effects of task structure, decision rule and social motive. Organizational Behavior and Human Decision Processes, 87, 227-252.

Beersma, B., \& De Dreu, C. K. W. (2003). Social motives in integrative negotiation: The mediating influence of procedural fairness. Social Justice Research, 16, 217-239.

Bornstein, G., Kugler, T., \& Ziegelmeyer, A. (2004). Individual and group decisions in the centipede game: Are groups more 'rational' players? Journal of Experimental Social Psychology, 40, 599-605.

Bornstein, G. B., \& Yaniv, I. (1998). Individual and group behavior in the ultimatum game: Are groups more 'rational' players? Experimental Economics, 1, 101-108.

Crump, L., \& Glendon, I. (2003). Towards a multiparty negotiation paradigm. International Negotiation, 8, 197-234.

Davis, J. H. (1992). Some compelling intuitions about group consensus decisions, theoretical and empirical research, and interpersonal aggregation phenomena: Selected examples, 1950-1990. Organizational Behavior and Human Decision Processes, 52, 3-38.

De Cremer, D., \& Van Dijk, E. (2002). Reactions to group success and failure as a function of group identification: A test of the goaltransformation hypothesis in social dilemmas. Journal of Experimental Social Psychology, 38, 435-442.

De Dreu, C. K. W., \& Carnevale, P. (2003). Motivational bases of information processing and strategy in conflict and negotiation. In M. P. Zanna (Ed.), Advances in experimental social psychology (Vol. 35, pp. 235-291). San Diego, CA: Academic Press.

De Dreu, C. K. W., Weingart, L. R., \& Kwon, S. (2000). Influence of social motives on integrative negotiation: A meta-analytic review and test of two theories. Journal of Personality and Social Psychology, 78, 889-905.

De Kwaadsteniet, E. W., Van Dijk, E., Wit, A., \& De Cremer, D. (2006). Social dilemmas as strong versus weak situations: Social value orientations and tacit coordination under resource uncertainty. Journal of Experimental Social Psychology, 42, 509-516.

Eisenberger, R., Kuhlman, D. M., \& Cotterell, N. (1992). Effects of social values, effort training, and goal structure on task persistence. Journal of Research in Personality, 26, 258-272.

Gallagher, M., Laver, M., \& Mair, P. (2001). Representative government in modern Europe, (3rd ed.) New York: McGraw Hill.

Gamson, W. A. (1964). Experimental studies of coalition formation. In L. Berkowitz (Ed.), Advances in experimental social psychology

(Vol. 1, pp. 81-110). New York:

Academic Press.

Insko, C. A., Schopler, J., Graetz, K. A., Drigotas, S. M., Currey, D. P., Smith, S. L. et al. (1994). Interindividual-intergroup discontinuity in the prisoner's dilemma game. Journal of Conflict Resolution, 38, 87-116.

Joireman, J. A., Kuhlman, D. M., Van Lange, P. A. M., Doi, T., \& Shelley, G. P. (2003). Perceived rationality, morality, and power of social choice as a function of interdependence structure and social value orientation. European Journal of Social Psychology, 33, 413-437

Kahan, J. P., \& Helwig, R. A. (1971). Coalitions: A system of programs for computer-controlled bargaining games. General Systems, 16, 31-41.

Kelley, H. H., \& Thibaut, J. W. (1978). Interpersonal relations: A theory of interdependence. New York: Wiley.

Kerr, L. N., McCoun, R. J., \& Kramer, G. P. (1996). Bias in judgment: comparing individuals and groups. Psychological Review, 103, 687-719.

Komorita, S. S., \& Meek, D. D. (1978). Generality and validity of some theories of coalition formation. Journal of Personality and Social Psychology, 36, 392-404.

Komorita, S. S., \& Parks, C. D. (1995). Interpersonal relations: Mixed-motive interaction. Annual Review of Psychology, 46, 183-207. 
Liebrand, W. B. G., Jansen, R. W. T. L., Rijken, V. M., \& Suhre, C. J. M. (1986). Might over morality: Social values and the perception of other players in experimental games. Journal of Experimental Social Psychology, 22, 203-215.

Martin, L. W., \& Stevenson, R. T. (2001). Government formation in parliamentary democracies. American Journal of Political Science, 45, 33-50.

Messick, D. M., \& McClintock, C. G. (1968). Motivational bases of choice in experimental games. Journal of Experimental Social Psychology, 4, $1-25$.

Michener, H. A., Fleishman, J. A., Vaske, J. J., \& Statza, G. R. (1975). Minimum resource and pivotal power theories: A competitive test in four-person coalitional situations. Journal of Conflict Resolution, 19, 89-107.

Miller, D. T. (1999). The norm of self-interest. American Psychologist, 54, 1053-1060.

Murnighan, J. K. (1978a). Models of coalition behavior: Game theoretic, social psychological, and political perspectives. Psychological Bulletin, 85, 1130-1153.

Murnighan, J. K. (1978b). Strength and weakness in four coalition situations. Behavioral Science, 23, 195-208.

Parks, C. D. (1994). The predictive ability of social values in resource dilemmas and public good games. Personality and Social Psychology Bulletin, 20, 431-438.

Platow, M. J. (1994). An evaluation of the social desirability of prosocial self-other allocation choices. Journal of Social Psychology, 134, 61-68.

Poltzer, J. T., Mannix, E. A., \& Neale, M. A. (1998). Interest alignment and coalitions in multiparty negotiation. Academy of Management Journal, 41, 42-54.

Rusbult, C. E., \& Van Lange, P. A. M. (2003). Interdependence, interaction, and relationships. Annual Review of Psychology, 54, 351-375.

Schopler, J., \& Insko, C. A. (1992). The discontinuity effect in interpersonal and intergroup relations: Generality and mediation. In W. Stroebe \& M. Hewstone (Eds.), European review of social psychology (Vol. 3, pp. 121-151). Chichester, UK: England: Wiley.

Tyler, T. R., Huo, Y. J., \& Lind, A. E. (1999). Two psychologies of conflict resolution: Differing antecedents of pre-experience choices and post-experience evaluations. Group Processes $\mathcal{E}^{\circ}$ Intergroup Relations, 2, 99-118.
Van Beest, I., Van Dijk, E., De Dreu, C. K. W., \& Wilke, H. A. M. (2005). Do-no-harm in coalition formation: Why losses inhibit exclusion and promote fairness cognitions. Journal of Experimental Social Psychology, 41, 609-617.

Van Beest, I., Van Dijk, E., \& Wilke, H. A. M. (2004a). The interplay of self-interest and equity in coalition formation. European Journal of Social Psychology, 34, 547-565.

Van Beest, I., Van Dijk, E., \& Wilke, H. A. M. (2004b). Resources and alternatives in coalition formation: The effects on payoff, self-serving behavior, and bargaining length. European Journal of Social Psychology, 34, 713-728.

Van Beest, I., Wilke, H. A. M., \& Van Dijk, E. (2003). The excluded player in coalition formation. Personality and Social Psychology Bulletin, 29, 237-247.

Van Lange, P. A. M. (1999). The pursuit of joint outcomes and equality in outcomes: An integrative model of social value orientation. Journal of Personality and Social Psychology, 77, 337-349.

Van Lange, P. A. M., Otten, W., De Bruin, E. N. M., \& Joireman, J. A. (1997). Development of prosocial, individualistic, and competitive orientations: Theory and preliminary evidence. Journal of Personality and Social Psychology, 73, 733-746.

Van Lange, P. A. M., \& Kuhlman, D. M. (1994). Social value orientations and impressions of a partner's honesty and intelligence: A test of the might versus morality effect. Journal of Personality and Social Psychology, 67, 126-141.

Wildschut, T., Pinter, B., Vevea, J. L., Insko, C. A., \& Schopler, J. (2003). Beyond the group mind: A quantitative review of the interindividualintergroup discontinuity effect. Psychological Bulletin, 129, 698-722.

Williams, K. D. (2001). Ostracism: The power of silence. New York: Guilford.

Willis, R. H. (1962). Coalitions in the triad. Sociometry, 25, 358-376.

Zadro, L., Williams, K. D., \& Richardson, R. (2004). How low can you go? Ostracism by a computer is sufficient to lower self-reported levels of belonging, control, self-esteem, and meaningful existence. Journal of Experimental and Social Psychology, 40, 560-567.

Zadro, L., Williams, K. D., \& Richardson, R. (2005). Riding the 'O' train: Comparing the effects of ostracism and verbal dispute on targets and 
sources. Group Processes $\mathcal{E}^{2}$ Intergroup Relation, 8, $125-143$.

Paper received 4 October 2006; revised version accepted 6 April 2007.

\section{Biographical notes}

ILJA VAN BEEST is associate professor of psychology at Leiden University. He did his MA in psychology at the University of Amsterdam and PhD at Leiden University. His research interests include coalition formation, social exclusion, and symptom perception.

RUDY B. ANDEWEG is professor of political science at Leiden University. He did his MA in Law at Leiden University, his MA in political Science at the University of Michigan, Ann Arbor, and his $\mathrm{PhD}$ at Leiden University. His research interests include coalition government, political leadership, and political representation.

LUKAS KONING is a PhD candidate at Leiden University. He did his MA in Psychology at Leiden University. His research interests include deception, power and negotiation.

PAUL A. M. VAN LANGE is professor of psychology at the VU University Amsterdam, and also holds a Professorship at the University of Leiden. He did his MA and PhD at the University of Groningen, The Netherlands. His research interests focus on interdependence and social interaction, cooperation and competition, and interpersonal orientations. 